\title{
BOLETIM BIBLIOGRÁFICO
}

\section{ENDEREÇOS ÚTEIS NA INTERNET 1}

http://www.releituras.com

No início, o, na época recém aposentado Arnaldo Nogueira Júnior, pretendia apenas compartilhar textos com amigos via e-mail. Um dia um amigo lhe propôs que colocasse os textos à disposição dos internautas e assim nasceu a idéia de fazer um site. O Releituras é um site que tem como objetivo divulgar trabalhos de escritores. No link releituras, o leitor tem à sua disposição mais de 700 textos, de 210 escritores nacionais e estrangeiros. Em biografia, o espaço é dedicado a autores consagrados, como Mário de Andrade, Adélia Prado e Barão de Itararé. Ao acessar a biografia de um dos autores, é possível ainda ler os textos deste autor disponíveis no site. Quinzenalmente há a publicação de uma tira humorística e todo mês um texto recebe a ilustração de um artista gráfico. A página ainda abre espaço a novos escritores. Os textos enviados ao Releituras serão submetidos a análise e, os que forem selecionados, serão publicados. Há ainda sugestão de links relacionados a vestibular e páginas que divulgam e se relacionam com o próprio Releituras. Estão disponíveis ainda um serviço de busca e de cadastro para que o internauta receba por e-mail as novidades do site.

http://www.tver.org.br/

A ONG TVer tem por objetivo principal contribuir para a melhoria da qualidade da programação da TV brasileira. Propõe que se discutam a televisão e os direitos dos telespectadores, já que a atuação da TV está diretamente ligada aos problemas da sociedade, ainda mais os relacionados com o público infanto-juvenil, tais como violência, gravidez na adolescência, exploração do trabalho infantil. Segundo pesquisas, as crianças brasileiras passam boa parte do tempo em frente à televisão. O site do TVer é um espaço interativo. No link 'Você faz a crítica', o internauta pode deixar sua opinião sobre a programação. A participação também se dá através de enquetes e de um fórum sobre vários temas relacionados a televisão. $\mathrm{O}$ internauta pode ainda se cadastrar para receber notícias via

1. Pesquisa e redaçâo de Patrícia Carla dos Santos, assistente da revista Comunicaşão e Educaçâo. 
e-mail. Há ainda no site textos de vários autores com ponto de vista sobre os programas de televisão, além de pesquisas e teses, links e bibliografia especializada na área. No link 'Educação' há uma oficina on line sobre violência, que visa estimular a reflexão sobre a programação da TV brasileira.

\section{http://www.multirio.rj.gov.br/seculo21}

O conteúdo do site Século XXI é dirigido a educadores de jovens e adolescentes. O site visa relacionar assuntos sobre a juventude, tais como sexualidade, trabalho, música, violência, com aqueles que permeiam o já complexo século XXI. Por enquanto, estão em pauta os temas funk \& rap, violência urbana e novo mundo do trabalho. Ao acessar o endereço acima, o internauta deve primeiro clicar em um dos temas, cada qual estruturado a partir da palavra chave. A página tem diversas chaves. Cada chave apresenta seu tema específico, abordando os cinco enfoques expressos em suas letras: $\mathrm{C}$ - conceito, $\mathrm{H}$ - hoje, $\mathrm{A}$ - atividades pedagógicas, $\mathrm{V}$ - vitrine de material de apoio, E - relato de experiências. Através desta chave o internauta pode navegar pelos diversos conteúdos de cada tema, bastando clicar em uma de suas letras.

No link Para entender o século XXI, o internauta tem acesso a diversos textos debatendo os principais temas do século e suas implicações. São eles: revolução tecnológica, globalização, cultura, mídia, desigualdade social, trabalho e violência.

\section{http://www.baraoemrevista.org}

O Barão em Revista é um site voltado para a divulgação da cultura. A página publica artigos com críticas de espetáculos de teatro e de dança, filmes, exposições e CDs. Há ainda vários textos sobre cidadania, relato de experiências, além de entrevistas com artistas e pessoas relacionadas a estas e outras áreas. O site contém ainda uma agenda de eventos atualizada.

\section{http://www.eca.usp.br/comueduc}

Este é o novo endereço virtual da revista Comunicação \& Educação. Com design reformulado, a página facilita a consulta aos artigos publicados na revista. Estes podem ser consultados através dos links sumários, seções, autores e artigos - onde estão organizados tematicamente. A página oferece também assinatura on line. Em breve estará disponível a busca de artigos por palavras-chave. Há um link com o curso de pós-graduação lato sensu Gestão de Processos Comunicacionais, além de acesso a endereços de núcleos da Escola de Comunicações e Artes da USP e de outras instituições ligadas às temáticas de comunicação e educação, como também dos sites já citados nesta seção Endereços úteis na Internet. 